XXVI Congresso de Iniciação Cientifica Unicamp
17 a 19 de outubro Campinas I Brasil

\title{
Desenvolvimento de recobrimentos nanométricos via técnica Layer-by-layer para captura seletiva de células tumorais
}

\section{Giulia Grassa Lima*, João Batista Maia Rocha Neto, Marisa Masumi Beppu.}

\section{Resumo}

Neste estudo, foram desenvolvidos filmes finos compostos por ácido hialurônico e quitosana utilizando a técnica Layerby-Layer (LbL) a fim de capturar células tumorais prostáticas. Investigou-se a influência das condições de pH e número de bicamadas no potencial seletivo dos recobrimentos e em suas propriedades físico-químicas.

\section{Palavras-chave:}

Câncer de próstata, Ácido Hialurônico, Adesão celular.

\section{Introdução}

O câncer de próstata é um tumor de crescimento lento que possui, quando diagnosticado em suas fases iniciais, grandes chances de cura. Dessa forma, é necessário a busca de métodos de detecção rápidos e de marcadores prognósticos para o $\mathrm{CaP}$. Estudo recente desenvolveu filmes compostos por ácido hialurônico (HA) e quitosana (CHI) em lâminas de vidro via LbL que apresentaram significativa seletividade na captura de células tumorais, explorando a interação CD44-HA ${ }^{1}$. CD44 é um receptor extracelular superexpresso em células tumorais e possuem como principal ligante a molécula de HA. Por sua vez, a técnica LbL trata-se de uma deposição alternada de polieletrólitos de cargas opostas. Neste estudo, foram desenvolvidos filmes de $\mathrm{HA} / \mathrm{CHI}$ via $\mathrm{LbL}$ em lamínulas de vidro, variando-se as condições de $\mathrm{pH}(3,0$ e $5,0)$ e número de bicamadas $(3,5 ; 10,5$ e 20,5$)$. Esperavase investigar a influência de outro substrato, assim como das condições de preparo citadas, nas propriedades físico-químicas e no potencial seletivo dos recobrimentos na captura da linhagem tumoral prostática PC3. Os filmes foram caracterizados utilizando-se as técnicas de Perfilometria, UV-Visível, Microscopia de Força atômica (AFM) e Ângulo de contato.

\section{Resultados e Discussão}

Os resultados de Perfilometria indicam que os filmes preparados em $\mathrm{pH} 3,0$ são mais espessos do que os filmes preprados em $\mathrm{pH} 5,0$, independente do número de bicamadas. No que se refere à disponibilidade de grupos carboxílicos do HA, os resultados de UV-Vis mostram que os filmes preparados em $\mathrm{pH} 3,0$ possuem maior quantidade de grupos funcionais livres, dada a maior absorbância do azul de alciano (AA), corante específico para grupos carboxílicos que foi utilizado para tingir os filmes. Por sua vez, as imagens de AFM apontam os filmes preparados em $\mathrm{pH} 5 \mathrm{com}$ menor rugosidade. As medidas de ângulo de contato indicam os filmes preparados em pH 3,0 com o maior caráter hidrofílico.

Todos esses resultados (Figura 1) são reflexo da densidade de cargas dos polileletrólitos $\mathrm{HA}$ e $\mathrm{CHI}$ na faixa de $\mathrm{pH}$ estudada. $\mathrm{O}$ valor de $\mathrm{pKa}$ da $\mathrm{CHI}$ é aproximadamente 6,0, enquanto o pKa do HA é 2,9. Dessa forma, as cadeias de $\mathrm{CHI}$ encontram-se altamente carregadas na faixa de $\mathrm{pH}$ estudada. Por sua vez, as moléculas de HA encontram-se parcialmente carregadas em $\mathrm{pH} 3,0$ e altamente carregadas em $\mathrm{pH}$ 5,0. Desta maneira, a menor ionização do $\mathrm{HA}$ em $\mathrm{pH}$ 3,0 faz com que se torne necessária uma maior deposição deste para compensar as cargas positivas disponíveis da $\mathrm{CHI}$, o que consequentemente aumenta a espessura dos filmes, a quantidade de grupos carboxílicos e a hidrofilicidade ${ }^{1}$. Em $\mathrm{pH} 5,0$, sob uma alta densidade de cargas, ambas as cadeias polieletrolíticas assumem uma conformação linear. Essa conformação adquire um caráter enovelado quando a densidade de carga é diminuída, o que ocorre para a molécula de $\mathrm{HA}$ em $\mathrm{pH} 3,0$, aumentando a rugosidade dos recobrimentos. Filmes preparados com 3,5 bicamadas em ambos os valores de $\mathrm{pH}$ apresentaram significativa seletividade para a linhagem PC3. No entanto, os resultados de adesão celular para os filmes mais espessos não foram bem sucedidos. Sugere-se que ocorreu um processo de entumescimento em múltiplas regiões dos mesmos, agravado pela condição de $\mathrm{pH}$ dos ensaios de adesão.

\begin{tabular}{|c|c|c|c|c|c|c|}
\cline { 2 - 7 } \multicolumn{1}{c|}{} & \multicolumn{2}{c|}{ Espessura (nm) } & \multicolumn{2}{c|}{ Abs. AA em 617 nm } & \multicolumn{2}{c|}{ Ângulo de contato em $0^{\circ}$} \\
\hline $\mathrm{nHH}$ & 3,0 & 5,0 & 3,0 & 5,0 & 3,0 & 5,0 \\
\hline 3,5 & 23,27 & 24,54 & 0,102 & 0,072 & 32,70 & 32,70 \\
\hline 10,5 & 497,33 & 54,45 & 1,110 & 0,245 & 44,05 & 53,25 \\
\hdashline 20,5 & 1490,84 & 380,41 & 1,473 & 0,876 & 44,95 & 54,00 \\
\hline
\end{tabular}

Figura 1. Medidas de espessura, absorbância do AA e ângulo de contato, onde $n$ é o número de bicamadas.

\section{Conclusões}

Foi possível construir filmes de $\mathrm{HA} / \mathrm{CHI}$ em lamínulas de vidro com propriedades físico-químicas similares àquelas observadas em filmes produzidos em lâminas de vidro ${ }^{1}$. A significativa seletividade apresentada pelos filmes $\mathrm{HA} / \mathrm{CHI}$ aponta possibilidades para aplicações diversas, tais como mecanismos rápidos de diagnóstico e biosensoriamento.

\section{Agradecimentos}

Ao PIBIC, ao Lequip, à Prof. ${ }^{-2}$ Dr. ${ }^{a}$ Marisa Beppu pela oportunidade, ao João B.M.R. Neto pela mentoria.

${ }^{1}$ ROCHA NETO, J.B. M. DESENVOLVIMENTO DE FILMES FINOS FUNCIONAIS VIA TÉCNICA DE LAYER-BY-LAYER VISANDO CAPTURA SELETIVA DE CÉLULAS TUMORAIS. 2016. 70f. Dissertação (Mestrado em Engenharia Química) - Universidade Estadual de Campinas, São Paulo. 2016. 